\title{
Psychoanalysis: The Influence of Freud's Theory in Personality Psychology
}

\author{
Songyang Zhang ${ }^{1}$ \\ ${ }^{1}$ High School Affiliated to Renmin University of China, Beijing 100080, China
}

\begin{abstract}
Psychoanalysis theory is Sigmund Freud's theory of personality that attributes thoughts and actions to unconscious motives and conflicts. The purpose of this paper is to examine the influence of Sigmund Freud's psychoanalysis theory on other personality psychologists. It illustrates the relationship of different psychologist with Sigmund Freud, and further analyze the influence by comparing the similarities and different between traditional psychoanalysis theory with the new theories proposed by various psychologist. The conclusion of this paper is that the influence of Sigmund Freud towards other personality psychologist shed light on the overall development of Personality Psychology as a unique subject.
\end{abstract}

Keywords: Personality psychology, psychoanalysis, psychological types, Freud influence

\section{INTRODUCTION}

Psychology is the study of mind and behavior. Psychology, merging from biology and philosophy, has many different schools of thought and subdivided subjects. One of the most famous school in psychology is psychoanalysis, marking by the interpretation of dream and other Freudian theory. The Psychoanalysis or psychodynamic theory arose from the $19^{\text {th }}$ century, which focus on the unconsciousness and dream analysis. Psychoanalysis is the first wave of psychotherapy development which has a huge influence on the development of psychology overall and other psychologists. Personality psychology is a subdivided subject which studies the psychological type and individual personality. In this paper, it discusses the development of Freud's personality theory as well as how his theory influences other famous psychoanalysis psychologists: Anna Freud, Carl Jung, and Otto Rank.

\section{Sigmund Freud}

Sigmund Freud was the most influential person in the field of psychology. He was the founder of psychanalysis, also the first person who proposed psychoanalysis personality theory.

\subsection{Early experience}

Freud was born in 1856 in Moravia. When Freud was born, his father was forty years old and his mother was only twenty [14]. In his childhood, Freud's father was strict and despotic [14]. However, his mother cared about him. He loved his mother in a special way, which influenced Freud's theory of Oedipus complex.

\subsection{Id, Ego, and Super ego}

Id, Ego, and Superego were the three layers of personality in Freud's theory. It was the basic structure of individual personality, according to Freud [5]. Id represented human's biological instinct. Freud described Id as "pleasure principle" and "primary-process thought", representing Id fulfill human need

immediately in order to relief the nervous feeling [5]. Id is the most innate quality of human which represent their physiological desire. Ego used "reality principle" [5]. It was the process of rationalization. Freud also called ego as the "second-process thought" [5]. Freud compared the relationship between the ego and the id to that between a charioteer and his horses: the horses provide the energy and drive, while the charioteer provides direction [12]. Super ego represented the conscience, which people already formed in their early childhood.

The combination of Id, Ego, and Superego forms the behavior and personality of an individual, which represented by their behavior in the society and their interaction with others. Id, Ego, and Superego theory is the fundamental theory in Freud's personality theory.

\subsection{Defense mechanism}

Anxiety was the signal of danger, representing that the ego was in a threatened situation [4]. As a result, ego must use different types of defense mechanisms to reduce anxiety. The defense mechanisms included repression, denial, reaction formation, projection, regression, rationalization, displacement, and sublimation [4]. Repression was the most common used mechanism, characterized by the unconscious replacement of conscious memories. It made people to "forget" traumatic memories. Freud regarded repression as an inner psychic process [1]. Repression was 
the basis of Freudian theory in personality psychology and the root of neurotic behavior.

Other defense mechanism include denial, which is blocking events from awareness and the refusing to experience the events. Projection is that individual attributing their own unacceptable thoughts, feeling and motives to another person. Displacement involves in satisfying an impulse with a substitute object. There are also many other defense mechanisms that people use to facing traumatic events. The defense mechanism that a person utilizes when facing their childhood trauma can in some way shape their personality and influence their personality development.

\subsection{Criticism}

Although Freud influenced the field personality psychology, there were many criticisms towards his theory. Horton, in the journal of abnormal psychology, directly pointed out that Freud's theory was "dangerously inaccurate" [8]. Moreover, an article discussing Freud's contribution illustrated that "the judgement of time seems to be running against him", indicating that Freud's theory cannot be regarded as valid scientifically [7].

\section{ANNA FREUD}

Anna Freud was the daughter of Sigmund Freud. She was analyzed by Sigmund Freud for four years. She dedicated to her father's psychanalysis system. However, instead of focusing on the adulthood dream and interpretation, Anna Freud only analyzed children.

\subsection{Children psychology}

Anna's psychoanalysis subject changed from adult to primary children. She had made a huge contribution to the development of children psychology. According to Anna's theory, the children's internal world and external environment have a mutual interaction between each other [19]. Also, Anna Freud's research showed various techniques in treating the disease caused by developmental disturbances and problems in children [19].

\subsection{Elaboration on defense mechanism}

Anna Freud, in the journal the Ego and the Mechanisms of Defense, elaborated on Sigmund Freud's theory in the defense mechanism and described how defense mechanism works in detail [3]. It was one of the most famous Anna Freud's work in the field of psychology. Also, it was Anna Freud who brought the word "defense mechanism" and "repression" into the public. According to Anna Freud, repression can be caused by any traumatic event and then stored in the unconscious mind, which caused neurotic mental disease [19]. Sigmund Freud, the father of Anna
Freud, complimented her work: "I agree with her opinion. However, her thought was derived from her own experience" [2].

\section{CARL JUNG}

\subsection{Early experience and relationship with Sigmund Freud}

Carl Jung was born in 1875 in Swiss. In his early years, he had an unfortunate family. His mother had an unstable mood, causing him to have a sense of alert to woman. It was also the reason why Jung opposed Freud's opinion on Oedipus complex. In 1907, Carl Jung met Sigmund Freud [6]. They had a close friendship at first. In the letter between Jung and Freud, it indicated that the unequal friendship between Jung and Freud was more like the relationship between the father and the son [6]. Freud even named Jung as the head of International Psychoanalytic Association, showing the intimacy and trust towards Jung [6]. However, Jung had his own view in personality psychology. They separated in 1913.

\subsection{Analytical psychology}

There were two main conflict between Jung and Freud. The first one was about libido. Freud viewed libido as the sextual instinct of human [5]. However, Jung thought libido was a broad life power. He did not view libido as an important factor contribute to the personality. Another definition of Jung viewing libido, was the power for "psyche", providing energy for people to think and feel [10] The second conflict was the method of dream analysis. Freud interpreted dreams using free analysis, and he interpreted it separately [16]. However, Jung thought the dream are connected with each other. And the dream were related to reality in a predictable and compensatory way [10].

\subsection{Psychological type}

Jung characterized people into primary type of psychological function, which contained two perceiving function: sensation and intuition, and two judging functions: thinking and feeling [11]. Then the function was divided into two attitude types: extraversion and introversion [11]. Psychological type was the main contribution of Jung to personality psychology which integrated his theory with psychoanalysis and personality. MBTI, the most widely used personality test, was constructed based on Jung's personality theory, which indicated that the psychological type can be used to characterized constant individual perception and judgement [15]. 
Freud's theory about Oedipus complex and individual personality, which caused the divergence between Rank and Freud.

Although there are many criticisms towards Freud, people still cannot deny the contribution and influence of Freud and psychoanalysis in the field of personality psychology. Further investigation and researches should be conducted based on the personality psychology and psychoanalysis.

\section{REFERENCES}

[1] Billig, M. (2006). A Psychoanalytic Discursive Psychology: From consciousness to unconsciousness. Discourse Studies. https://doi.org/10.1177/1461445606059546

\subsection{The Trauma of Birth}

The book concluded the Rank's central idea from 1924 to 1927 [13]. In the famous work of Rank, he proposed a "preoedipal" stages which took over Freud's oedipal stages, and consisted of the primordial relation of the infant to the mother [9]. Rank believed that the birth was an interruption of people's life which people spent the rest of their life to recover [18].

\subsection{The Psychology and the Soul}

The Psychology and the Soul was another famous work of Otto Rank after his divergence with Freud. In the book, by describing the history of psychology, anthropology and philosophy, Rank proposed his idea on personality psychology: individual personality was formed under the influence of culture and social environment [17]. Also, Rank explored the true meaning of psychology: "a way of observing relationships and relativities" [17]. In the book, Rank also posed criticisms toward Freud's Interpretation of Dreams: "the book is therapy, not psychology" [17].

\section{CONCLUSION}

Sigmund Freud's psychoanalysis theory in personality psychology largely influenced other famous psychoanalytic psychologist: Anna Freud, Carl Jung, and Otto Rank. Anna Freud inherited Sigmund Freud's theory in psychoanalysis and dream interpretation, but shifted the focus into child psychology. She also further elaborated on Freud's theory of defense mechanism and repression, which considered as the most influential work of Anna Freud. Carl Jung, as the student of Freud, established analytical psychology from psychoanalysis. He also proposed his own theory in psychological types. The theory of introversion and extroversion influenced personality psychology, causing tremendous amount of research based on the characterization of psychological types. Otto Rank, the closest friend and student of Freud, developed his theory based on psychoanalysis theory. However, he challenged
[2] Burlingham, D. T., \& Freud, A. (1944). Infants without families: the case for and against residential nurseries. Infants without families: the case for and against residential nurseries.

[3] Freud, A. (1936). The ego's defensive operations considered as an object of analysis. The Ego and the Mechanisms of Defense. https://doi.org/10.1097/00005053-194903000-00010

[4] Freud, S. (1915). Instincts and their Vicissitudes. Standard Edition, Vol. 14. https://doi.org/10.1017/CBO9781107415324.004

[5] Freud, S. (1995). The Ego and the Id (1923). In The Id and the Ego and Other Works. https://doi.org/10.1097/00000441-196111000-00027

[6] Freud, S., Jung, C. G., McGuire, W., McGlashan, A., Manheim, R., Hull, R., \& Carrington, F. (1994). The Freud/Jung letters: The correspondence between Sigmund Freud and C. G. Jung (abridged ed.). Bollingen series, 94.

[7] Grayling, A. C. (2002). Scientist or storyteller? The Guardian. Retrieved from https://www.theguardian.com/books/2002/jun/22/socia lsciences.gender

[8] Horton, L. H. (1916). Scientific method in the interpretation of dreams. With a theory to explain the dream-process as apperceptive trial-and-error. Journal of Abnormal Psychology, 10(6), 369-399. https://doi.org/10.1037/h0070297

[9] James Lieberman, E., Kramer, R., \& Richter, G. C. (2012). The letters of Sigmund Freud and Otto rank: Inside psychoanalysis. The Letters of Sigmund Freud and Otto Rank: Inside Psychoanalysis. https://doi.org/10.1177/0957154X13483218

[10] Jung, C. G. (1935). Modern Man in Search of a Soul. The Journal of Nervous and Mental Disease. https://doi.org/10.1097/00005053-193506000-00052

[11] Jung, C. G., Baynes, H. G., \& Beebe, J. (2016). Psychological types. Psychological Types. https://doi.org/10.4324/9781315512334

[12] Lapsley, D. K., \& Stey, P. C. (2012). Id, Ego, and Superego. In Encyclopedia of Human Behavior: Second Edition. https://doi.org/10.1016/B978-0-12-3750006.00199-3

[13] Leitner, M. (1997). Too Rankian for the Freudians, or 
too Freudian for the Rankians: Otto Rank's contributions to psychoanalysis in the 1920s. Journal of the American Academy of Psychoanalysis. https://doi.org/10.1521/jaap.1.1997.25.1.37

[14] Lowmax, J. W. (2007). Freud: A Life For Our Time. The Journal of Clinical Psychiatry. https://doi.org/10.4088/JCP.v68n1223c

[15] Myers Briggs Foundation. (2016). The Myers and Briggs Foundation - MBTI ${ }^{\circledR}$ Basics.

[16] Parsons, T. (1974). The interpretation of dreams by Sigmund
Daedalus. https://doi.org/10.2307/20024191

[17] Rank, O. (1996). Psychology and the soul. Journal of Religion and Health. https://doi.org/10.1007/BF02354948

[18] Rank, O. (2013). The Trauma of Birth in Its Importance for Psychoanalytic Therapy. The Psychoanalytic Review. https://doi.org/10.1521/prev.2013.100.5.669

[19] Tischler, L. (2014). Anna Freud: A new look at development. British Journal of Psychotherapy. https://doi.org/10.1111/bjp.12083 